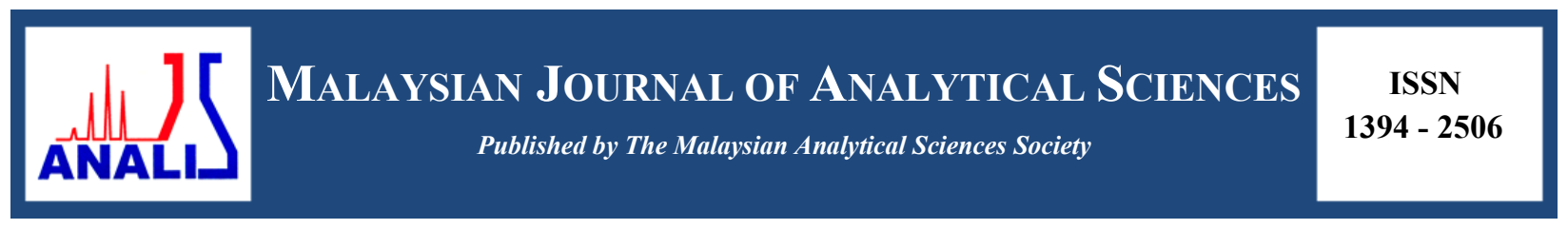

\title{
VOLTAMMETRIC DETERMINATION OF REACTIVE BLACK 5 (RB5) IN WASTE WATER SAMPLES FROM THE BATIK INDUSTRY
}

\author{
(Penentuan Voltammetrik Bagi Reaktif Black 5 (RB5) Dalam Sampel Air Sisa Dari Industri \\ Batik)
}

\author{
Nur Syamimi Zainudin ${ }^{1,2}$, Mohamad Hadzri Yaacob ${ }^{1 *}$, Noor Zuhartini Md Muslim \\ ${ }^{I}$ School of Health Sciences, Forensic Science Programme \\ Universiti Sains Malaysia, 16150 Kubang Kerian, Kelantan, Malaysia \\ ${ }^{2}$ Faculty of Applied Science, \\ Universiti Teknologi MARA Cawangan Pahang, Kampus Jengka, 26400 Bandar Jengka, Pahang, Malaysia \\ *Corresponding author: hadzri@usm.my
}

Received: 19 April 2016; Accepted: 30 September 2016

\begin{abstract}
A cyclic voltammetry (CV) and differential pulse cathodic stripping voltammetry (DPCSV) studies of RB5 in Britton-Robinson buffer (BRB) at a hanging mercury dropping electrode (HMDE) are described. CV was carried out by cathodic and anodic potential scan over the range of $+200 \mathrm{mV}$ to $-800 \mathrm{mV}$ with no accumulation time and three well-defined pH-dependent cathodic peaks were observed. The effects of different scan rates, $\mathrm{pH}$ of BRB, repetitive cycle and increasing concentrations on the peak height and peak potential of the analyte were studied. The results showed that RB5 dye was adsorbed and irreversibly reduced at the mercury electrode, mainly under diffusion controlled in the optimum $\mathrm{pH} 4.0$ of BRB. By using DPCSV, pH of BRB and various instrumental parameters such as scan rate, accumulation time, accumulation potential and pulse amplitude that may affect the peak height of RB5 were investigated and optimized for RB5 determination. Under the optimized parameters, the peak height was found to be linear with RB5 concentration in the range from $2.5 \times 10^{-7} \mathrm{~mol} \mathrm{~L}^{-1}$ to $2.0 \times 10^{-6} \mathrm{~mol} \mathrm{~L}^{-1}$. A detection limit $(3 \mathrm{SD} / \mathrm{m})$ of $1.3 \times 10^{-8} \mathrm{~mol} \mathrm{~L}^{-1}$ was achieved. The precision of the developed method in terms of RSD was $0.55 \%$ for intra-day measurement and $0.55 \%, 0.24 \%$ and $0.40 \%$, for inter-day measurements, respectively. The developed method was successfully applied in the determination of RB5 in batik wastewaters with the mean recovery of $83.97 \pm 4.78 \%$ to $97.93 \pm 5.45 \%\left(0.5 \times 10^{-6}\right.$ mol L $\left.{ }^{-1}\right), 95.91 \pm 2.68 \%$ to $103.49 \pm 1.32 \%\left(1.0 \times 10^{-6} \mathrm{~mol} \mathrm{~L}^{-1}\right)$ and $99.17 \pm 0.75 \%$ to $105.12 \pm 0.28 \%\left(2.0 \times 10^{-6} \mathrm{~mol} \mathrm{~L}^{-1}\right)$. The developed method is considered sensitive, precise, accurate, rugged, robust, fast and low cost for routine analysis of RB5 dye in batik wastewaters over the UV-VIS spectrometry method.
\end{abstract}

Keywords: Reactive Black 5, differential pulse cathodic stripping, Britton-Robinson buffer, hanging mercury dropping electrode, batik wastewater samples

\begin{abstract}
Abstrak
Kajian voltammetri berkitar (CV) dan voltammetri perlucutan denyut kebezaan (DPCSV) terhadap pewarna RB5 dalam larutan penimbal Britton-Robinson (BRB) menggunakan elektrod jatuhan raksa tergantung (HMDE) dihuraikan. CV dijalankan dengan mengimbas potential kathodik dan anodik dari $+200 \mathrm{mV}$ ke $-800 \mathrm{mV}$ tanpa masa pengumpulan dan tiga puncak diperhatikan selepas imbasan. Kesan perbezaan kadar imbasan, pH BRB, imbasan berkitar yang berulang dan peningkatan kepekatan RB5 ke atas ketinggian dan nilai keupayaan puncak dikaji. RB5 yang dijerap dan diturunkan secara tidak berbalik pada permukaan elektrod merkuri adalah dibawah kawalan difusi pada pH BRB yang optimum iaitu 4.0. Dengan menggunakan DPCSV, pH BRB dan parameter-parameter peralatan yang memberi kesan kepada ketinggian puncak seperti kadar imbasan, masa pengumpulan, keupayaan pengumpulan dan amplitud denyut telah dioptimumkan untuk analisis RB5. Ketinggian puncak berkadar terus dengan kepekatan RB5 dalam julat dari $2.5 \times 10^{-7}$ mol L ${ }^{-1}$ hingga $2.0 \times 10^{-6} \mathrm{~mol} \mathrm{~L}^{-1}$. Had pengesanan adalah $1.3 \times 10^{-8} \mathrm{~mol} \mathrm{~L}^{-1}$. Ketepatan (RSD) kaedah yang dibangunkan adalah $0.55 \%$ untuk hari yang sama, manakala $0.55 \%, 0.24 \%$ dan $0.40 \%$ untuk tiga
\end{abstract}




\section{Nur Syamimi et al: VOLTAMMETRIC DETERMINATION OF REACTIVE BLACK 5 (RB5) IN WASTE WATER SAMPLES FROM THE BATIK INDUSTRY}

hari yang berbeza. Kaedah yang dibangunkan berjaya diuji bagi penentuan RB5 dalam air sisa batik dengan purata kebolehdapatan $83.97 \pm 4.78 \%$ sehingga $97.93 \pm 5.45 \%\left(0.5 \times 10^{-6} \mathrm{~mol} \mathrm{~L}^{-1}\right), 95.91 \pm 2.68 \%$ sehingga $103.49 \pm 1.32 \%\left(1.0 \times 10^{-6}\right.$ $\left.\mathrm{mol} \mathrm{L}^{-1}\right)$ dan $99.17 \pm 0.75 \%$ sehingga $105.12 \pm 0.28 \%\left(2.0 \times 10^{-6} \mathrm{~mol} \mathrm{~L}^{-1}\right)$. Kaedah yang dibangunkan adalah sensitif, tepat, lasak, teguh, cepat dan menjimatkan bagi analisis rutin kandungan RB5 dalam air sisa batik berbanding kaedah spektrofotometri UV-VIS.

Kata kunci: Reaktif Black 5, voltammetri perlucutan denyut kebezaan, penimbal Britton-Robinson, elektrod jatuhan raksa tergantung, sampel air sisa batik

\section{Introduction}

The textile industry is considered as one of the major water consumers. It utilizes a large volume of water and chemicals for the wet processing of the textiles and can contribute to the water bodies pollution [1,2]. Homemade batik industry is a part of the textile industry and preliminary studies have shown that wastewaters discharged from this particular industry contain dyes, heavy metals, grease, wax and also suspended solids with high chemical oxygen demand (COD) [3, 4].

Azo dyes are considered as the oldest and the largest class of synthetic organic dyes. They are also considered as dyes with the largest shade range and are commonly used [5]. They account for $60 \%$ to $70 \%$ of the total organic dyes, have bright and high colour intensity, extensively used in textile, food, drug, cosmetic, automobile, leather and in the paper making industries $[6,7,8]$.

Reactive Black 5 (RB5) or [2,7-naphthalenedisulfonic acid, 4-amino-5-hydroxy-3,6-bis ((4 - ( (2 (sulfooxy) ethyl) sulfonyl) phenyl) azo)-tetrasodium salt], which chemical structure is shown in Figure 1, is categorized in the reactive vinyl sulphonate azo dye due to the presence of $-\mathrm{N}=\mathrm{N}$ - bonds combined with vinylsulphone as the reactive groups [9]. The two azo groups which act as chromophores enable the dyes to absorb light in the visible spectrum and are also responsible for the corresponding colours. These reactive groups are covalently bonded to - $\mathrm{OH}$ or $\mathrm{NH}_{2}$ groups that are present in the materials to give excellent wash fastness property $[10,11,12]$.

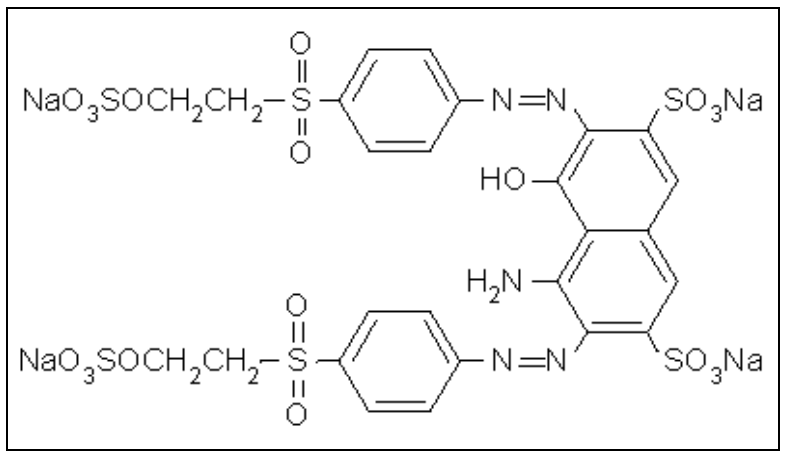

Figure 1. Chemical structure of RB5

Several analytical methods for the analysis of azo dyes and their intermediates in various samples have been developed and most of the methods are based on the electrophoresis, chromatographic and spectroscopic method $[13,14]$. The voltammetric method allows for an analysis without or with minimal samples pre-treatment, has comparable selectivity and sensitivity over the chromatographic method, applicability over a wide concentration range, fast analysis, low cost on instrumentation and maintenances and is able to perform both individual and simultaneous analyses $[15,16]$.

This paper describes the cyclic voltammetric (CV) studies of RB5 dye using a hanging mercury dropping electrode (HMDE) as the working electrode in the Britton-Robinson buffer (BRB) to obtain qualitative information on the 
electrochemical reactions such as reversibility, adsorption and diffusion characteristics of a system. Differential pulse cathodic stripping voltammetric (DPCSV) studies of RB5 dye using the same HMDE and in the same BRB had then been carried out for RB5 dye determination in the wastewaters from local batik factories. With regards to the voltammetry method, no DPCSV technique for RB5 dye determination has been reported so far. It is also rarely reported for the analysis of azo dyes containing two azo groups in their chemical structures.

\section{Materials}

\section{Materials and Methods}

All chemicals used in this study were of analytical grade reagent and all solutions were prepared in deionized water. The RB5 dye standard $\left(\mathrm{MW}=991.82 \mathrm{gmol}^{-1}\right.$ ) was obtained from Sigma Aldrich, UK. For the preparation of $2.0 \mathrm{x}$ $10^{-4} \mathrm{molL}^{-1} \mathrm{RB} 5$ dye stock solution, $20 \mathrm{mg}$ of the RB5 dye standard was dissolved in $100 \mathrm{~mL}$ volumetric flask. The standard working solution of $2.0 \times 10^{-5} \mathrm{molL}^{-1}$ was prepared by the appropriate dilution of the stock solution. BRB solution as the supporting electrolyte was prepared in $1000 \mathrm{~mL}$ deionized water, composed of a mixture of $2.47 \mathrm{~g}$ boric acid (R\&M Chemicals, Canada), $2.30 \mathrm{~mL}$ glacial acetic acid (R\&M Chemicals, Canada) and $2.70 \mathrm{~mL}$ orthophosporic acid (R\&M Chemicals, Canada). Sodium hydroxide (Systerm, Italy) with the concentration of $0.1 \mathrm{M}$ was used to adjust the $\mathrm{pH}$ of the BRB solution to the desired value. High purity mercury, $99.99 \%$ (Merck, Germany) was used for HMDE.

\section{Instrumentations}

The voltammetric experiments were carried out using VA 757 Computrace Metrohm Voltammetric Analyzer with 663 VA Stand (Metrohm, Switzerland), consisted of Multi-Mode Electrode (MME) and a $40 \mathrm{~mL}$ capacity voltammetric cell. The MME consisted of a HMDE as the working electrode (WE), a platinum wire as the auxiliary electrode (AE) and an $\mathrm{Ag} / \mathrm{AgCl}$ as the reference electrode (RE). The VA 757 was connected to a computer for data processing and for all $\mathrm{pH}$ measurements, the $\mathrm{pH}$ meter (Hanna Instruments, UK) was employed.

\section{Voltammetric measurement: Cyclic voltammetry}

BRB solution with the volume of $9 \mathrm{~mL}$ was placed into a voltammetric cell and purged by a stream of purified nitrogen for at least 15 minutes. RB5 dye standard solution $\left(2.0 \times 10^{-3} \mathrm{molL}^{-1}\right)$ with the volume of $1 \mathrm{~mL}$ was then spiked to give a final concentration of $2.0 \times 10^{-4} \mathrm{molL}^{-1}$ and the solution was repurged for 2 minutes. The RB5 dye was scanned from $+200 \mathrm{mV}$ to $-800 \mathrm{mV}$ (cathodic direction) and switched to $+200 \mathrm{mV}$ (anodic direction) with a scan rate $(v)$ of $25 \mathrm{mV} / \mathrm{s}$ in various $\mathrm{pH}$ of the BRB solution (pH 2.0 to 12.0). The effect of various $v$ (25 to 200 $\mathrm{mV} / \mathrm{s})$, the effect of repetitive cycle ( 1 to 5 cycles) and the effect of dye concentrations on the peak height $\left(\mathrm{I}_{\mathrm{p}}\right)$ and peak potential $\left(\mathrm{E}_{\mathrm{p}}\right)$ of RB5 dye were investigated.

\section{Differential pulse stripping voltammetry}

BRB solution with the volume of $9 \mathrm{~mL}$ was placed into the voltammetric cell and purged by a stream of purified nitrogen for at least 15 minutes. RB5 dye standard solution $\left(2.0 \times 10^{-5} \mathrm{molL}^{-1}\right)$ with the volume of $1 \mathrm{~mL}$ was then spiked to give the final concentration of $2.0 \times 10^{-6} \mathrm{molL}^{-1}$ and the solution was repurged for 2 minutes. The initial operational parameters applied for the voltammetric measurements were the initial potential $\left(\mathrm{E}_{\mathrm{i}}\right)=+150 \mathrm{mV}$, final potential $\left(\mathrm{E}_{\mathrm{f}}\right)=-700 \mathrm{mV}, v=15 \mathrm{mV} / \mathrm{s}$, accumulation time $\left(\mathrm{t}_{\mathrm{acc}}\right)=0 \mathrm{~s}$, accumulation potential $\left(\mathrm{E}_{\text {acc }}\right)=0 \mathrm{mV}$ and pulse amplitude $=50 \mathrm{mV}$. Parameters such as $v, \mathrm{t}_{\mathrm{acc}}, \mathrm{E}_{\mathrm{acc}}$ and pulse amplitude were optimized to increase the response of the developed method.

The developed method was validated for linearity, limit of detection (LOD), limit of quantification (LOQ), precision, repeatability, accuracy, ruggedness and robustness to verify the suitablity for the extended purposes according to the approach proposed by Miranda et al. [17]. The LOD and LOQ were calculated by the equations; $\mathrm{LOD}=3 \mathrm{SD} / \mathrm{m}$ and $\mathrm{LOQ}=10 \mathrm{SD} / \mathrm{m}$, where $\mathrm{SD}$ is the standard deviation of the three replicate determinations of the RB5 dye at the lowest concentration on the calibration curve and $\mathrm{m}$ is the slope of the regression equation [18]. The RB5 dye standard solution at the concentration of $2.0 \times 10^{-6} \mathrm{molL}^{-1}$ was applied for intra-day and inter-day precision, ruggedness and robustness with five replicate $(n=5)$ measurements. The ruggedness of the developed method was investigated using the same voltammetry analyzer (VA 757), but had been conducted by two different analysts [19] and was also analyzed by using two different voltammetry analyzers (VA 757 and VA 797) but only 
conducted by one analyst [20] under the same optimum parameters. The robustness was carried out by examining the effect of a small variation of $v, \mathrm{t}_{\mathrm{acc}}$, time interval analysis after RB5 dye standard preparation and $\mathrm{pH}$ of BRB solution on the response.

Collection, preservation and analysis of wastewaters from the batik industry

Wastewaters from the batik industry were obtained from nine batik factories, located at Kota Bharu and Pantai Cahaya Bulan, Kelantan, Malaysia. The wastewaters were collected from two different dyebaths at each factory. The wastewaters were analyzed using the developed DPCSV technique without the prior samples pre-treatment and extraction by spiking $1 \mathrm{~mL}$ of the wastewater samples into the $9 \mathrm{~mL}$ BRB solution.

Recovery studies of the RB5 dye in wastewaters from the batik industry

To study the accuracy and reproducibility of the developed DPCSV technique, recovery experiments were carried out using the standard addition method.

\section{UV-VIS Spectrophotometry analysis of the RB5 dye}

The results obtained by the developed DPCSV technique were compared with the UV-VIS Spectrophotometry method using Spectrophotometer Cary 100, USA. The double beam mode was employed for the overall analysis from the start wavelength of $700 \mathrm{~nm}$ to the stop wavelenghth of $300 \mathrm{~nm}$ with the rate of $600 \mathrm{~nm} / \mathrm{min}$.

\section{Electrochemical behaviour of the RB5 dye}

\section{Results and Discussion}

Cyclic voltammetric studies of the RB5 dye were carried out in $0.04 \mathrm{M} \mathrm{BRB}$ solution from pH 2.0 to 12.0 with $v$ of $25 \mathrm{mV} / \mathrm{s}$. From the cyclic voltammogram obtained, BRB solution at $\mathrm{pH} 4.0$ was observed to be the optimum condition with $\mathrm{I}_{\mathrm{p}}$ of $298 \mathrm{nA}$ for RB5 dye reduction at the HMDE, as shown in Figure 2. Three well-defined reduction peaks at $-79.80 \mathrm{mV},-258 \mathrm{mV}$ and $-568 \mathrm{mV}$ were obtained for the first, second and third peak, respectively. No oxidation peaks were observed which confirmed that the RB5 dye was irreversibly reduced at the mercury electrode. The second reduction peak was referred to as the analytical signal due to its higher sensitivity compared to the first and third reduction peak of the RB5 dye [21].

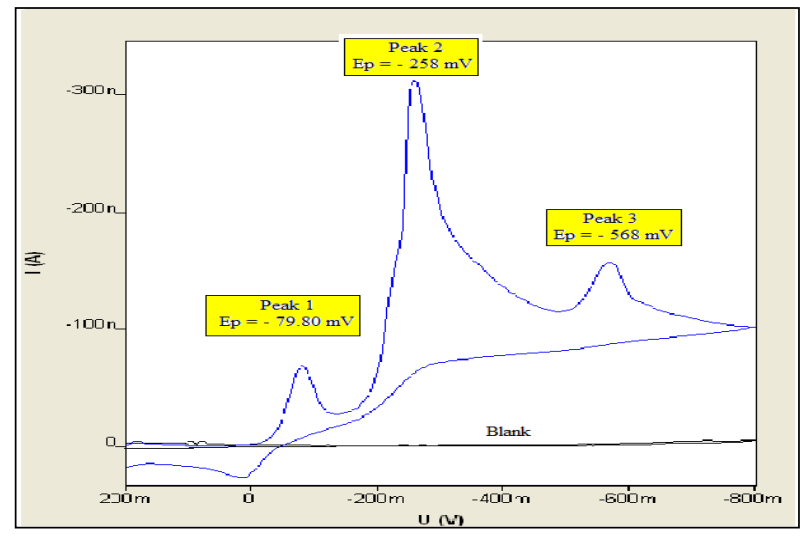

Figure 2. Cyclic voltammogram of $2 \times 10^{-4} \mathrm{molL}^{-1} \mathrm{RB} 5$ dye in BRB solution at $\mathrm{pH}$ 4.0.Experimental condition: $\mathrm{E}_{\mathrm{i}}=+200 \mathrm{mV}, \mathrm{E}_{\text {switch }}=-800 \mathrm{mV}, \mathrm{E}_{\mathrm{f}}=+200 \mathrm{mV}$ and $v=25 \mathrm{mV} / \mathrm{s}$

The first two obtained reduction peaks were suggested due to the subsequence reduction process of the two azo groups to amines. Both hydroxyl and amino groups were electron donating substituents in the RB5 dye compound. The first reduction peak was suggested from the reduction process of the azo with the hydroxyl group and followed by the reduction process of the other azo with amino group, which gave the second reduction peak on the 
voltammograms. The reduction process of the azo with amino group was more difficult due to the electron distribution in this functional group [22].

The effect of $\mathrm{pH}$ of BRB solution on the $\mathrm{E}_{\mathrm{p}}$ was studied from $\mathrm{pH} 2.0$ to 12.0. The results showed that the $\mathrm{E}_{\mathrm{p}}$ of RB5 dye was shifted to the more negative potentials with the increased $\mathrm{pH}$ indicating that the electron transfer was accompanied by proton transfer in the reduction process $[23,24]$. The reduction process was easier to take place in a medium rich with $\mathrm{H}^{+}$ions and more difficult in a medium with low $\mathrm{H}^{+}$ions [25] and the reduction process of RB5 dye was $\mathrm{pH}$ dependent $[26,27]$.

The effects of scan rate $(v)$ from 25 to $200 \mathrm{mV} / \mathrm{s}$ on the $\mathrm{E}_{\mathrm{p}}$ and $\mathrm{I}_{\mathrm{p}}$ of the RB5 dye were observed under the same experimental conditions. The results showed that by increasing the $v$, the $\mathrm{E}_{\mathrm{p}}$ shifted to more negative potentials and accompanied with the increase of the $\mathrm{I}_{\mathrm{p}}$. The increase of $\mathrm{I}_{\mathrm{p}}$ indicated an adsorption phenomenon of the RB5 dye at the surface of the mercury electrode [28, 29]. A linear relationship was observed between $\log \mathrm{I}_{\mathrm{p}}$ against $\log v$ with a slope of $0.5282\left(R^{2}=0.9982, n=6\right)$, as shown in Figure 3. The slope of 0.5282 was close to the theoretical value of 0.5 , which indicated that the reduction process of RB5 dye was mainly controlled by diffusion [30, 31].

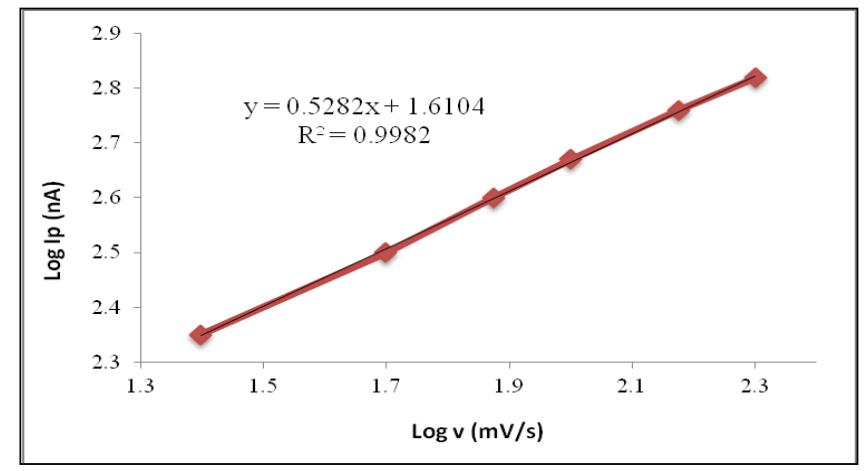

Figure 3. Plot of $\mathrm{I}_{\mathrm{p}}$ to the $\log v$ for $2 \times 10^{-4} \mathrm{molL}^{-1} \mathrm{RB} 5$ dye in BRB solution at $\mathrm{pH} 4.0$

The effect of the RB5 dye concentrations was investigated and the results showed that the $\mathrm{E}_{\mathrm{p}}$ of RB5 dye at -258 $\mathrm{mV}$ showed no significant change in the peak position and the $\mathrm{I}_{\mathrm{p}}$ of the RB5 dye increased with the increasing concentration of RB5 dye. This phenomenon confirmed the adsorption of the RB5 dye at the mercury electrode surface [32]. No new peak was observed with the increasing RB5 dye concentration at both the cathodic and anodic directions, which indicated that the obtained reduction peaks were due to respective RB5 dye and not from other electroactive species that may be present in the BRB solution [33].

The effect of repetitive cycles on the $I_{p}$ of the RB5 dye was studied with five cycles. The $I_{p}$ decreased in the second cycle and was almost constant for the third, fourth and fifth cycle, as shown in Figure 4. This meant that the variation of $I_{p}$ was controlled by diffusion in the experimental condition [34] and RB5 dye had the adsorption behaviour at the surface of the mercury electrode [35].

\section{Differential pulse stripping voltammery of the RB5 dye: The effects of $\mathrm{pH}$ of BRB solution}

Differential pulse cathodic stripping voltammetry of $2 \times 10^{-6} \mathrm{molL}^{-1} \mathrm{RB} 5$ dye was studied in $0.04 \mathrm{M}$ BRB solution from $\mathrm{pH} 2.0$ to 12.0 . BRB solution at $\mathrm{pH} 2.5$ was considered as the optimum $\mathrm{pH}$ since the highest $\mathrm{I}_{\mathrm{p}}$ and welldefined shape of the first reduction peak were obtained. The voltammogram of RB5 dye in BRB solution at pH 2.5 is shown in Figure 5. The $\mathrm{E}_{\mathrm{p}}$ of RB5 dye peak shifted to more negative potentials as the $\mathrm{pH}$ of BRB solution increased, indicating the involvement of $\mathrm{H}^{+}$in the reduction process of RB5 dye [36]. 


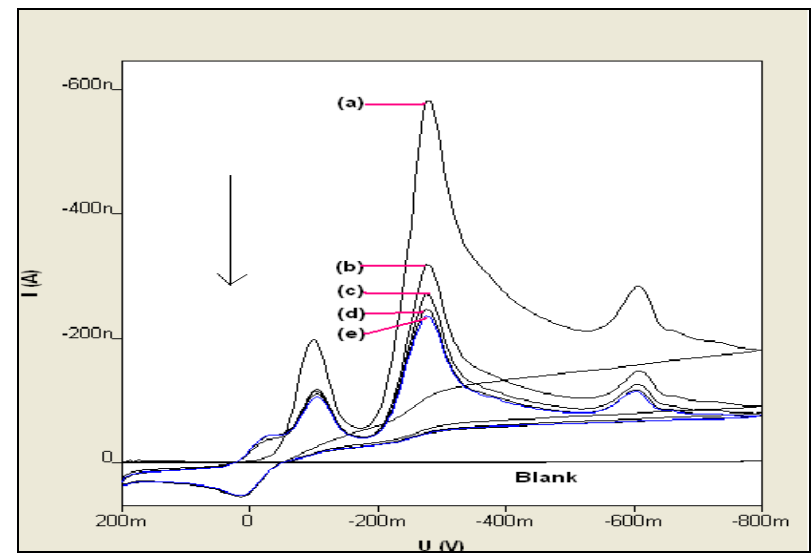

Figure 4. Cyclic voltammograms of repetitive cycles of $2 \times 10^{-4} \mathrm{molL}^{-1} \mathrm{RB} 5$ dye in BRB solution at $\mathrm{pH}$ 4.0. (a) First (b) second (c) third (d) fourth and (e) fifth cycle

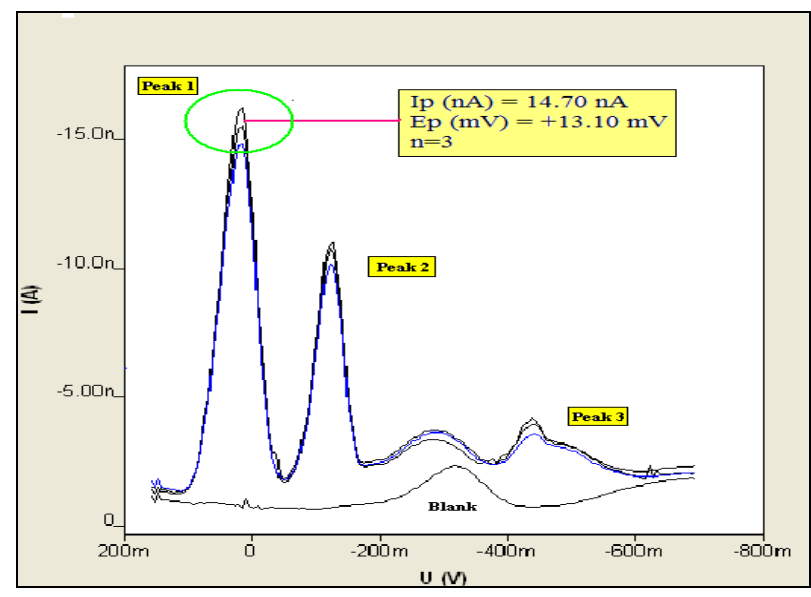

Figure 5. Voltammogram of $2 \times 10^{-6} \mathrm{molL}^{-1} \mathrm{RB} 5$ dye in BRB solution at $\mathrm{pH}$ 2.5. Parameters conditions: $\mathrm{E}_{\mathrm{i}}=+150 \mathrm{mV}, \mathrm{E}_{\mathrm{f}}=-700 \mathrm{mV}, v=15 \mathrm{mV} / \mathrm{s}, \mathrm{t}_{\mathrm{acc}}=0 \mathrm{~s}, \mathrm{E}_{\mathrm{acc}}=0 \mathrm{mV}$ and pulse amplitude $=50 \mathrm{mV}$

\section{Optimization of the operational parameters}

It is very important to optimize all the parameters that may influence the measurements in order to obtain the optimum response [37]. The effects of scan rate $(v)$, accumulation time $\left(t_{\text {acc }}\right)$, accumulation potential $\left(\mathrm{E}_{\mathrm{acc}}\right)$ and pulse amplitude on the $\mathrm{I}_{\mathrm{p}}$ of $2 \times 10^{-6} \mathrm{molL}^{-1} \mathrm{RB} 5$ dye were studied in the BRB solution at $\mathrm{pH} 2.5$.

\section{The effect of scan rate (v)}

The relationships of $\mathrm{I}_{\mathrm{p}}$ of the RB5 dye to various $v$ such as $5,10,15,30$ and $40 \mathrm{mV} / \mathrm{s}$ were observed using the unoptimum parameters. The $v$ of $5 \mathrm{mV} / \mathrm{s}$ was chosen as the optimum condition since it gave the highest $\mathrm{I}_{\mathrm{p}}$ of the first reduction peak of the RB5 dye which was $16.10 \mathrm{nA}$.

\section{The effect of accumulation time ( $\left.t_{\text {acc }}\right)$}

Accumulation of electroactive species at the electrode contributed to a high response in the electroanalytical measurements [38]. Accumulation time $\left(\mathrm{t}_{\mathrm{acc}}\right)$ is the period of time given for the RB5 dye to accumulate onto the mercury electrode surface before being analyzed. The dependence of $I_{p}$ on the $t_{a c c}$ was studied at concentration of 2 $\times 10^{-6} \mathrm{molL}^{-1} \mathrm{RB} 5$ dye over the range from 0 to $110 \mathrm{~s}$. 
At $t_{\text {acc }}$ of $0 \mathrm{~s}$, the first reduction peak of RB5 dye gave a higher $I_{p}$ compared to the second reduction peak. The $I_{p}$ of the second reduction peak had become dominant, starting from $t_{\text {acc }}$ of $10 \mathrm{~s}$ and onwards. The second reduction peak was referred as the analytical signal for further optimization since it showed higher $I_{p}$ as the $t_{\text {acc }}$ increased. From Figure 6 , the $\mathrm{I}_{\mathrm{p}}$ increased with the increasing $\mathrm{t}_{\text {acc }}$ from 0 to $80 \mathrm{~s}$, then became constant with the longer times. The $\mathrm{t}_{\mathrm{acc}}$ of $80 \mathrm{~s}$ was chosen as the optimum condition with $\mathrm{I}_{\mathrm{p}}$ of $121 \mathrm{nA}$ at $\mathrm{E}_{\mathrm{p}}$ of $-88 \mathrm{mV}$.

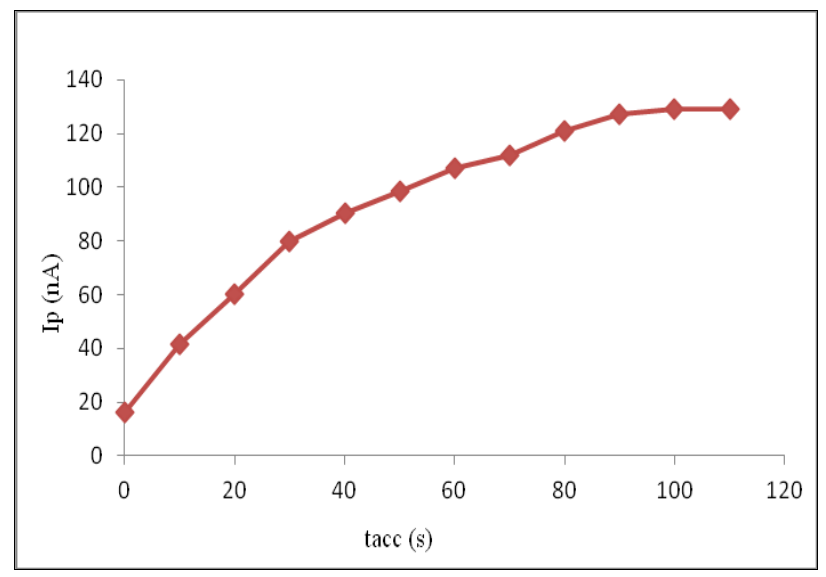

Figure 6. Effect of various $t_{\text {acc }}$ on the $I_{p}$ of second reduction peak of $2 \mathrm{mg} / \mathrm{L}$ RB5 dye in BRB solution at $\mathrm{pH} 2.5$. Initial instrumental parameters were $\mathrm{E}_{\mathrm{i}}=+150 \mathrm{mV}, \mathrm{E}_{\mathrm{f}}=-650 \mathrm{mV}, v=5 \mathrm{mV} / \mathrm{s}, \mathrm{E}_{\mathrm{acc}}=0 \mathrm{mV}$ and pulse amplitude $=50 \mathrm{mV}$

As suggested by Tavares et al. [39], the increase of $I_{p}$ with $t_{a c c}$ was due to the accumulation of RB5 dye at the mercury electrode surface in a larger amount, since longer time was given for the accumulation process to occur. The constant $I_{p}$ that was obtained at longer $90 \mathrm{~s}$ had been suggested due to the saturation of the accumulated RB5 dye at the electrode surface [40].

The effect of accumulation potential $\left(E_{\text {acc }}\right)$

Accumulation potential $\left(\mathrm{E}_{\mathrm{acc}}\right)$ was the potential for the RB5 dye to be accumulated at the surface of mercury electrode, whereas an optimum $\mathrm{E}_{\text {acc }}$ was the most appropriate potential for the accumulation process to take place. The effect of $E_{a c c}$ on the $I_{p}$ of the second reduction peak was evaluated over the range of 0 to $-100 \mathrm{mV}$ for $2 \times 10^{-6}$ $\mathrm{molL}^{-1} \mathrm{RB} 5$ dye. The maximum response was observed at $\mathrm{E}_{\mathrm{acc}}$ of $0 \mathrm{mV}$ with $\mathrm{I}_{\mathrm{p}}$ of $120 \mathrm{nA}$ at $\mathrm{E}_{\mathrm{p}}$ of $-82.10 \mathrm{mV}$. It indicated that the accumulation of RB5 dye at the electrode surface effectively occured at $0 \mathrm{mV}$.

\section{The effect of pulse amplitude}

According to De Lima et al. [41], pulse amplitude is one of the factors that affect the sensitivity of voltammetric measurements. The effect of pulse amplitude on the $\mathrm{I}_{\mathrm{p}}$ was studied by measuring $2 \times 10^{-6} \mathrm{molL}^{-1} \mathrm{RB} 5$ dye within the range of 25 to $125 \mathrm{mV}$ of pulse amplitude, under the previous optimum parameters. Figure 7 shows that the $\mathrm{I}_{\mathrm{p}}$ has sharply increased at the range of pulse amplitude from 25 to $75 \mathrm{mV}$ and slowly decreased at higher values. The $\mathrm{E}_{\mathrm{p}}$ has shifted towards less negative directions as the values of pulse amplitude increased.

The pulse amplitude of $75 \mathrm{mV}$ was noted as the optimum condition due to the highest $\mathrm{I}_{\mathrm{p}}$ observed which was 223 $n A$ with $E_{p}$ at $-65.50 \mathrm{mV}$. By changing the pulse amplitude, the $E_{i}$ was changed from $+150 \mathrm{mV}$ to $+250 \mathrm{mV}$ and the $\mathrm{E}_{\mathrm{f}}$ was changed from $-650 \mathrm{mV}$ to $-600 \mathrm{mV}$ in order to observe the first reduction peak on the voltammograms. 


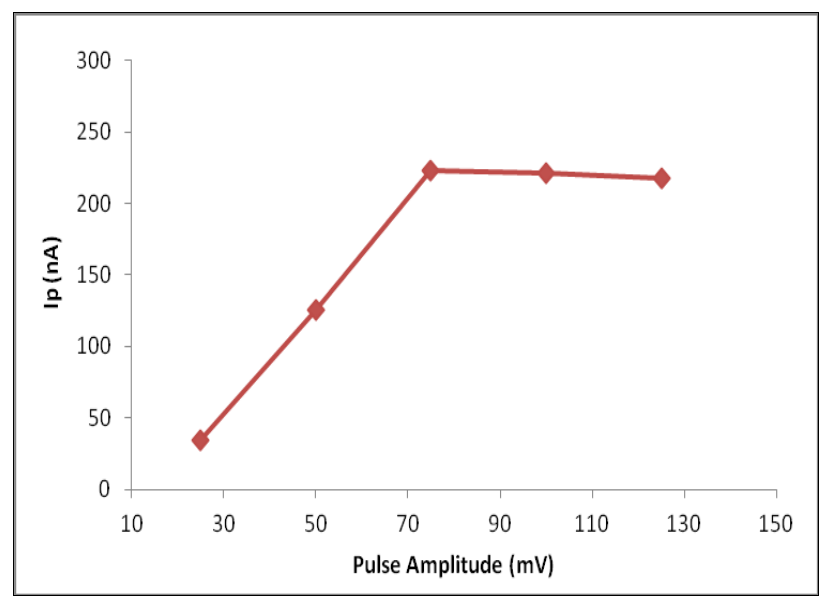

Figure 7. Effects of various pulse amplitudes on the $\mathrm{I}_{\mathrm{p}}$ of $2 \mathrm{mg} / \mathrm{L}$ RB5 dye in BRB solution at $\mathrm{pH} 2.5$. Initial instrumental parameters were $\mathrm{E}_{\mathrm{i}}=+150 \mathrm{mV}, \mathrm{E}_{\mathrm{f}}=-650 \mathrm{mV}, v=5 \mathrm{mV} / \mathrm{s}, \mathrm{t}_{\mathrm{acc}}=80 \mathrm{~s}$ and $\mathrm{E}_{\mathrm{acc}}=0 \mathrm{mV}$

By applying these optimized parameters, the $I_{p}$ was enhanced about 24 times, compared to the obtained $I_{p}$ by using the unoptimized parameters which was $9 \mathrm{nA}$ at $\mathrm{E}_{\mathrm{p}}$ of $-121 \mathrm{mV}$. Table 1 shows the optimum supporting electrolyte and instrumental parameters of the developed DPCSV technique of $2 \times 10^{-6} \mathrm{molL}^{-1} \mathrm{RB} 5$. These optimum parameters were then used to validate the developed method.

Table 1. Optimum supporting electrolyte and instrumental parameters of the developed DPSCV technique

\begin{tabular}{lc}
\hline Supporting Electrolyte and Instrumental Parameters & Optimum Value \\
\hline Britton-Robinson Buffer $(\mathrm{BRB})$ & $\mathrm{pH} 2.5$ \\
Initial Potential, $\mathrm{E}_{\mathrm{i}}(\mathrm{mV})$ & +250 \\
End Potential, $\mathrm{E}_{\mathrm{f}}(\mathrm{mV})$ & -600 \\
Scan Rate, $v(\mathrm{mV} / \mathrm{s})$ & 5 \\
Accumulation Time, $\mathrm{t}_{\mathrm{acc}}(\mathrm{s})$ & 80 \\
Accumulation Potential, $\mathrm{E}_{\mathrm{acc}}(\mathrm{mV})$ & 0 \\
Pulse Amplitude $(\mathrm{mV})$ & +75 \\
\hline
\end{tabular}

Validation of the developed method: Linearity, limit of detection, limit of quantification

The applicability of the developed DPCSV technique as an analytical method for the determination of RB5 dye standard solution was examined by measuring the obtained $I_{p}$ as the function of concentration under the optimum operational and instrumental parameters as shown in Table 1.

Two linear regions were observed and the $\mathrm{I}_{\mathrm{p}}$ of RB5 dye tended to maintain, starting at the concentration of $1.6 \mathrm{x}$ $10^{-5} \mathrm{molL}^{-1}$. As suggested by Geremedhin et al. [42] and Radi et al. [43], this phenomenon may be due to the limited adsorption of RB5 dye at the mercury electrode, which resulted from the saturation of the electrode surface. As shown in Figure 8, the first linear region demonstrated its linearity from $2.5 \times 10^{-7} \mathrm{molL}^{-1}$ to $2.0 \times 10^{-6} \mathrm{molL}^{-1}$ at five different concentrations of RB5 dye standard solution. The constructed calibration graph was represented by the linear equation of $\mathrm{I}_{\mathrm{p}}(\mathrm{nA})=115.61 \mathrm{x}-10.31$ with a correlation coefficient $\left(\mathrm{R}^{2}\right)$ of 0.9998 . The second region was linear from $3.0 \times 10^{-6} \mathrm{molL}^{-1}$ to $1.4 \times 10^{-5} \mathrm{molL}^{-1}$ with the regression equation of $\mathrm{I}_{\mathrm{p}}(\mathrm{nA})=11.76 \mathrm{x}+211.56$ and $\mathrm{R}^{2}$ of 0.9987 . The first linear region demonstrated a bigger slope than the second region, thus it was applied for RB5 
dye determination since a higher sensitivity had been offered for analysis [44]. The calculated LOD for the standard solution was $1.3 \times 10^{-8} \mathrm{molL}^{-1}$ and the LOQ was found to be $4.3 \times 10^{-8} \mathrm{~mol} \mathrm{~L}^{-1}$.

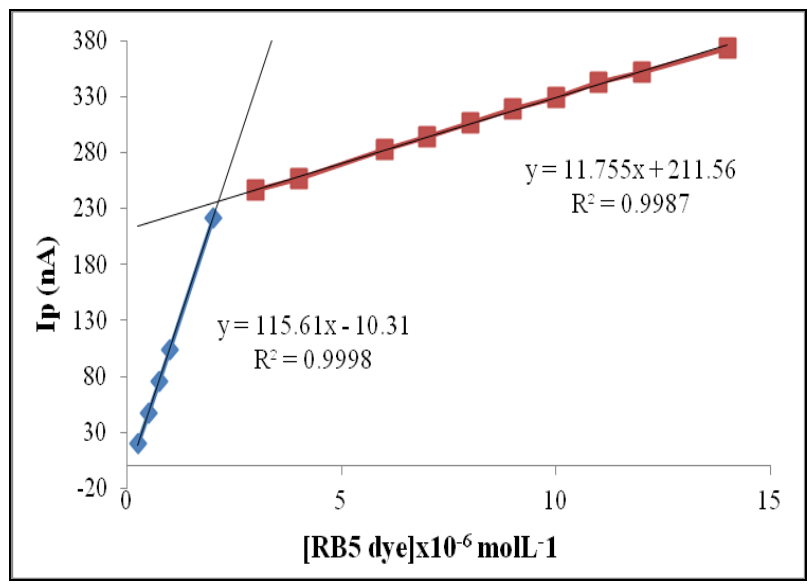

Figure 8. Two linear curves of RB5 dye in BRB solution at $\mathrm{pH} 2.5$. (a) $2.5 \times 10^{-7}$ to $2.0 \times 10^{-6} \mathrm{molL}^{-1}$ and (b) $3.0 \mathrm{x}$ $10^{-6}$ to $1.4 \times 10^{-5} \mathrm{molL}^{-1}$

\section{Precision}

The precision of the developed technique for RB5 dye determination was determined in five replicate measurements $(\mathrm{n}=5)$ at a concentration of $2.0 \times 10^{-6} \mathrm{molL}^{-1}$ [45]. The relative standard deviation (RSD) of $0.55 \%$ had been achieved for the measurements which indicated that the developed method was precise and confidence as the value was less than $2 \%$ [46]. The intra-day and inter-day repeatability studies were carried out by measuring $2.0 \times 10^{-6}$ molL ${ }^{-1} \mathrm{RB} 5$ dye for five replicates in three consecutive days using the developed technique. The RSD values for day 1,2 and 3 were $0.55 \%, 0.24 \%$ and $0.40 \%$, respectively which also indicated that the developed method was precise and confidence.

\section{Accuracy}

The accuracy of the developed technique was tested by spiking three known different concentrations of RB5 dye which were $5 \times 10^{-7} \mathrm{molL}^{-1}, 1.0 \times 10^{-6} \mathrm{molL}^{-1}$ and $2.0 \times 10^{-6} \mathrm{molL}^{-1}$ into a voltammetric cell containing BRB solution [47]. These spiked RB5 dye standard solutions were measured in three replicates $(n=3)$ and the discovered amounts of the spiked solutions in the cell were calculated using the equation of $\mathrm{I}_{\mathrm{p}}(\mathrm{nA})=115.61 \mathrm{x}-10.31$, where $\mathrm{x}$ is the found concentrations of RB5 dye in the voltammetric cell. The satisfactory recoveries of $99.94 \pm 3.15 \%$, $99.16 \pm 1.80 \%$ and $100.61 \pm 1.09 \%$ were respectively achieved for the spiked concentrations of $5 \times 10^{-7} \mathrm{molL}^{-1}, 1.0$ $\times 10^{-6} \mathrm{molL}^{-1}$ and $2.0 \times 10^{-6} \mathrm{molL}^{-1}$.

\section{Ruggedness}

The RSD values were $0.49 \%$ and $0.38 \%$ for the first and second analyst, respectively for the measurements using the same voltammetry analyzer (VA 757). The RSD values were $0.49 \%$ and $0.20 \%$ for the analysis using the respective VA 757 and VA 797 (different voltammetry analyzers) by the first analyst. From the two-tailed $F$ test, there were no significant differences between the obtained variances for RB5 dye when the measurements were performed by two different analysts with the same voltammetry analyzer and by the same analyst with two different voltammetry analyzers at the $5 \%$ significance level. Hence, the results indicated that the developed technique was considered rugged.

\section{Robustness}

By the two -tailed $F$ test at $95 \%$ confidence level, none of small variations of the $v(3$ and $7 \mathrm{mV} / \mathrm{s}), \mathrm{t}_{\text {acc }}(78$ and $82 \mathrm{~s})$, time interval analysis after the standard preparation ( 0,30 and 60 minutes) and $\mathrm{pH}$ of BRB solution ( $\mathrm{pH} 2.3$ and 2.7) 
had significantly influenced the obtained $\mathrm{I}_{\mathrm{p}}$ of RB5 dye at the concentration of $2.0 \times 10^{-6} \mathrm{molL}^{-1}$ with five replicate $(\mathrm{n}=5)$ measurements $[48,49]$.

\section{Determination of RB5 dye in wastewaters collected from the batik industry}

To evaluate the application to a real samples analysis, the developed DPCSV technique was used to analyze RB5 dye in wastewater samples which were collected from the local batik factories. The wastewater samples were analyzed by the developed technique under optimum parameters without any sample pre-treatment. Table 2 shows the content of RB5 in the collected batik wastewater samples.

Table 2. The concentrations of RB5 dye in the batik wastewater samples from the first and second dyebath

\begin{tabular}{|c|c|c|c|}
\hline $\begin{array}{l}\text { Samples } \\
\text { (First Dyebath) }\end{array}$ & $\begin{array}{l}\text { Concentration of RB5 } \\
\left(\times 10^{-6} \mathrm{~mol} / \mathrm{L}\right)\end{array}$ & $\begin{array}{c}\text { Samples } \\
\text { (Second Dyebath) } \\
\end{array}$ & $\begin{array}{c}\text { Concentration of RB5 } \\
\left(\times 10^{-6} \mathrm{~mol} / \mathrm{L}\right)\end{array}$ \\
\hline S1-A1 & 0.493 & S1-B1 & N.D \\
\hline S2-A1 & N.D & S2-B1 & N.D \\
\hline S3-A1 & 0.324 & S3-B1 & N.D \\
\hline S4-A1 & 0.236 & S4-B1 & N.D \\
\hline S5-A1 & N.D & S5-B1 & N.D \\
\hline S6-A1 & 0.421 & S6-B1 & 0.235 \\
\hline S7-A1 & 0.183 & S7-B1 & N.D \\
\hline S8-A1 & N.D & S8-B1 & N.D \\
\hline S9-A1 & N.D & S9-B1 & N.D \\
\hline
\end{tabular}

N.D: not detected

To verify these results, recovery experiments were carried out by spiking three different concentrations of RB5 standard solution with the concentrations of $0.5 \times 10^{-6}, 1.0 \times 10^{-6}$ and $2.0 \times 10^{-6} \mathrm{molL}^{-1}$ into the wastewaters collected from the batik factories that did not contain RB5 dye. The experiments were carried out using four wastewater samples (S1-B1, S2-B1, S5-B1 and S8-B1) with three replicate $(\mathrm{n}=3)$ measurements per each spiked concentration. The recoveries achieved for $0.5 \times 10^{-6}, 1.0 \times 10^{-6}$ and $2.0 \times 10^{-6} \mathrm{molL}^{-1} \mathrm{RB} 5$ dye were from $83.97 \pm$ 4.78 to $97.93 \pm 5.45 \%, 95.91 \pm 2.68$ to $103.49 \pm 1.32 \%$ and $99.17 \pm 0.75$ to $105.12 \pm 0.28 \%$, respectively. According to the $t$-test (two-tailed), there were no significant differences between the recovery and spiked value at the $95 \%$ confidence level with degree of freedom $(n-1=2)$, since all the calculated $t$ values in the experiment were lower than the theoretical $t$ value, which was $4.303[50,51]$. These good recovery values indicated that the matrixes did not affect the determination of RB5 dye in batik wastewater samples and it was suggested that the developed method can be applied for RB5 dye determination in the batik wastewater samples without any sample pretreatment. The recovery results are listed in Table 3.

\section{Comparison of the results by the developed DPCSV technique and spectrophotometry method}

The performance of the developed DPCSV technique in determining the RB5 dye was then compared against UVVIS spectrophotometry [52]. Spectrophotometry measurements of RB5 dye in the range of 300 to $700 \mathrm{~nm}$ had shown that the highest absorbance was obtained at $596 \mathrm{~nm}$ which was attributed to the diazo groups and responsible for the blue colour of the dye solution [53]. The calibration curve was constructed and a linear range was found from $1.0 \times 10^{-6}$ to $1.5 \times 10^{-4} \mathrm{molL}^{-1}$ with the regression equation of $\mathrm{y}=0.0225 \mathrm{x}+0.0287\left(\mathrm{R}^{2}=0.9991\right)$, as shown in Figure 9. The LOD and LOQ were $0.4 \times 10^{-7} \mathrm{molL}^{-1}$ and $1.3 \times 10^{-7} \mathrm{molL}^{-1}$, respectively. 
Table 3. Analytical results of RB5 dye in batik wastewater samples using the developed technique

\begin{tabular}{lcccc}
\hline Samples & $\begin{array}{c}\text { Spiked amount } \\
\left(\mathbf{x 1 0}^{-\mathbf{6}} \mathbf{m o l L}^{-\mathbf{1}} \mathbf{)}\right.\end{array}$ & $\begin{array}{c}\text { Found }^{\mathbf{a}} \text { amount } \\
\left(\mathbf{x 1 0}^{-\mathbf{6}} \mathbf{m o l L}^{-\mathbf{1}} \mathbf{)}\right.\end{array}$ & $\begin{array}{c}\text { Recovery } \pm \text { SD } \\
\mathbf{( \% )}\end{array}$ & $\begin{array}{c}\text { RSD } \\
\mathbf{( \% )}\end{array}$ \\
\hline S1-B1 & 0.5 & 0.44 & $88.30 \pm 7.69$ & 8.71 \\
& 1.0 & 0.97 & $97.37 \pm 1.42$ & 1.46 \\
& 2.0 & 1.99 & $99.75 \pm 0.66$ & 0.66 \\
S2-B1 & 0.5 & 0.44 & $88.07 \pm 7.99$ & 9.07 \\
& 1.0 & 0.98 & $98.30 \pm 3.60$ & 3.66 \\
& 2.0 & 2.10 & $105.12 \pm 0.28$ & 0.27 \\
S5-B1 & 0.5 & 0.42 & $83.97 \pm 4.78$ & 5.69 \\
& 1.0 & 0.96 & $95.91 \pm 2.68$ & 2.79 \\
& 2.0 & 1.99 & $99.61 \pm 0.43$ & 0.43 \\
S8-B1 & 0.5 & 0.49 & $97.93 \pm 5.45$ & 5.57 \\
& 1.0 & 1.03 & $103.49 \pm 1.32$ & 1.28 \\
& 2.0 & 1.98 & $99.17 \pm 0.75$ & 0.76 \\
\hline
\end{tabular}

${ }^{a}$ Average of three replicate measurements for each spiked concentration

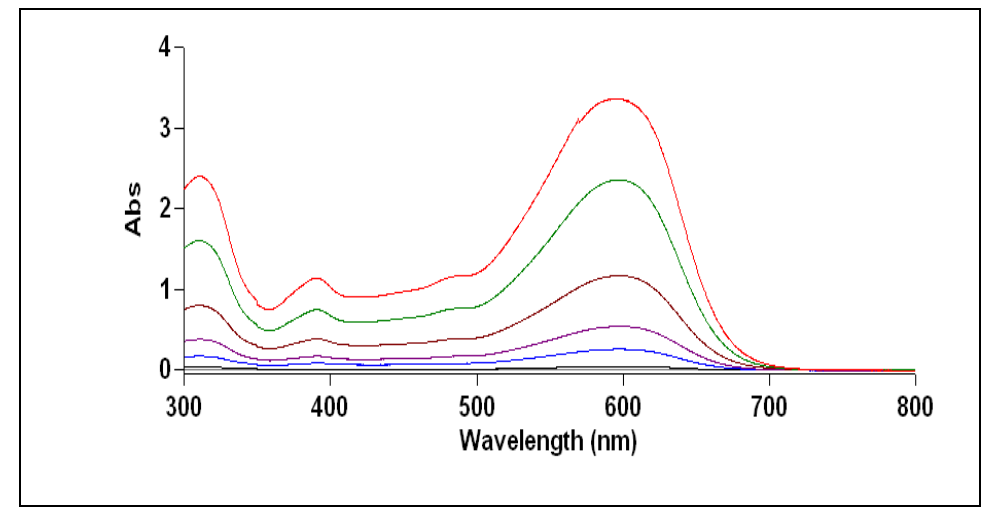

Figure 9. Spectra of RB5 dye with increasing concentration from $1.0 \times 10^{-6}$ to $1.5 \times 10^{-4} \mathrm{molL}^{-1}$

The results obtained by both developed DPCSV and spectrophotometry method in analyzing RB5 dye in the several wastewaters samples collected from the batik factories were then compared, as shown in Table 4. The developed DPCSV technique can be considered more sensitive as it had an ability to detect and determine the dye at a lower level compared to the UV-VIS Spectrophotometry method. 
Table 4. The concentrations of RB5 dye in the batik wastewater samples using two different methods

\begin{tabular}{lcc}
\hline \multirow{2}{*}{ Samples } & \multicolumn{2}{c}{ Concentration of RB5 $(\mathbf{x} \mathbf{1 0} \mathbf{- 6} \mathbf{~ m o l} / \mathbf{L})$} \\
\cline { 2 - 3 } & DPSV & UV-VIS \\
\hline S1-A1 & 0.493 & 0.471 \\
S2-A1 & N.D & N.D \\
S3-A1 & 0.324 & N.D \\
S4-A1 & 0.236 & N.D \\
S5-A1 & N.D & N.D \\
S6-A1 & 0.421 & N.D \\
S7-A1 & 0.183 & N.D \\
S8-A1 & N.D & N.D \\
S9-A1 & N.D & N.D \\
\hline
\end{tabular}

N.D: not detected

\section{Conclusion}

The developed DPCSV technique had been succesfully applied to determine the RB5 dye in wastewaters from the batik industry. The present method had an advantage that no prior extractions or samples pre-treatment were required. It was also found to be practically rapid, convenient, sensitive, accurate, precise, rugged, robust and low in cost compared to the UV-VIS Spectrophotometry method. Therefore, it could be an excellent alternative method for the routine determination of RB5 dye in batik wastewaters samples.

\section{Acknowledgement}

The authors gratefully acknowledge Universiti Sains Malaysia (USM) for awarding the Short Term Grant No: 304/PPSK/61312057. We would also like to thank Metrohm (Malaysia) Sdn Bhd for allowing us to use their instrument and also to all the laboratory staff of the School of Health Sciences, USM, Malaysia for their cooperation and assistance.

\section{References}

1. Ellouze, E., Tahri, N. and Amar, R. B. (2012). Enhancement of textile wastewater treatment process using nanofiltration. Desalination, 286: 16 - 23.

2. Norasikin, O., Mili, N., Siti, N. Z. and Nurul, A. B. M. (2010). Extraction of remazol brilliant orange 3R from textile wastewater using tetrabutyl ammonium bromide. Jurnal Teknologi, 53:29-39.

3. Nora'aini, A. and Suhaimi, N. S. (2009). Performance evaluation of locally fabricated asymmetric nanofiltration membrance for batik industry effluent. World Applied Sciences Journal, 5: 46 - 52.

4. Cristóvão, R. O., Tavares, A. P. M., Ferreira, L. A., Loureiro, J. M., Boaventura, R. A. R. and Macedo, E. A. (2009). Modeling the discoloration of a mixture of reactive textile dyes by commercial laccase. Bioresource Technology, 100: 1094 - 1099.

5. Xu, G., O'Dea, J. J. and Osteryoung, J. G. (1995). Surface reduction study of monoazo dyes by adsorptive square wave voltammetry. Dyes and Pigments, 30: $201-223$.

6. Muthukumar, M., Karuppiah, M. T. and Raju, G. B. (2007). Electrochemical removal of C.I acid orange 10 from aqueous solution. Separation and Purification Technology, 55: 198 - 205.

7. Bogdanowicz, R., Fabiańska, A., Golunski, L., Sobaszek, M., Gnyba, M., Ryl, J., Darowicki, K., Ossowski, T., Janssens, S. D., Haenen, K. and Siedlecka, E. M. (2013). Influence of the boron doping level on the electrochemical oxidation of the azo dyes at Si/BDD thin film electrodes. Diamonds and Related Materials, 39: $82-88$.

8. Solís, M., Solís, A., Pérez, H. I., Manjarrez, N. and Flores, M. (2012). Microbial decolouration of azo dyes: A review. Process Biochemistry, 47: 1723 - 1748. 
9. Tunc, O., Tanac1, H. and Aksu, Z. (2009). Potential use of cotton plant wastes for the removal of remazol Black B reactive dye. Journal of Hazardous Materials, 163: 187 - 198.

10. Yavuz, Y. and Shahbazi, R. (2012). Anodic oxidation of Reactive Black 5 dye using boron doped diamond anodes in a bipolar trickle tower reactor. Separation and Purification Technology, 85: $130-136$.

11. Méndez-Martínez, A. J., Dávila-Jiménez, M. M., Ornelas-Dávila, O., Elizalde-González, M. P., Arroyo-Abad, U., Sires, I. and Brillas, E. (2012). Electrochemical reduction and oxidation pathways for Reactive Black 5 dye using nickel electrodes in divided and undivided cells. Electrochimica Acta, 59: 140 - 149.

12. Jović, M., Stanković, D., Manojlović, D., Andelković, I., Milić, A., Dojčinović, B. and Roglić, G. (2013). Study of the electrochemical oxidation of reactive textile dyes using platinum electrode. International Journal of Electrochemical Sciences, 8: 168 - 183.

13. Bersier, P. M. and Berseir, J. (1986). Polarography and voltammetry of dyes and intermediates. Trends in Analytical Chemistry, 5(4): $97-102$.

14. Pinheiro, H. M., Touraud, E. and Thomas, O. (2004). Aromatic amines from azo dye reduction: Status review with emphasis on direct UV spectrophotometric detection in textile industry wastewaters. Dyes and Pigments, 61: $121-139$.

15. Fogg, A. G., Zanoni, M. V. B., Yusoff, A. R. H. M., Ahmad, R., Barek, J. and Zima, J. (1998). Polarographic and voltammetric determination of triazine-based reactive azo dyes with 4-carboxypyridyl and 1,4diazabicyclo[2,2,2] octanyl (DABCO) leaving groups. Analytica Chimica Acta, 362: 235 - 240.

16. Švorc, L., Sochr, J., Svitková, J., Riejav, M. and Bustin, D. (2013). Rapid and sensitive electrochemical determination of codeine in pharmaceutical formulations and human urine using a boron-doped diamond film electrode. Electrochimica Acta, 87: 503 - 510.

17. Miranda, M. P., del Rio, R., del Valle, M. A., Faundez, M. and Armijo, F. (2012). Use of fluorine-doped tin oxide electrodes for lipoic acid determination in dietary supplements. Journal of Electroanalytical Chemistry, 668: $1-6$.

18. Yardım, Y. and Şentürk, Z. (2013). Electrochemical evaluation and adsorptive stripping voltammetric determination of capsaicin or dihydrocapsaicin on a disposable pencil graphite electrode. Talanta, 112: 11 - 19.

19. Jain, R. and Rather, J. A. (2011). Stripping voltammetry of tinidazole in solubilized system and biological fluids. Colloids and Surfaces A: Physicochemical and Engineering Aspects, 378: 27 - 33.

20. Gaber, A. A. A., Ahmed, S. A. and Rahim, A. M. A. (2013). Cathodic adsorptive stripping voltammetric determination of Ribovirin in pharmaceutical dosage form, urine and serum. Arabian Journal of Chemistry, Article in Press.

21. Rather, J.A. and Wael, K. D. (2012). C60-funtionalized MWCNT based sensor for sensitive detection of endocrine disruptor vinclozolin in solubilized system and wastewater. Sensors and Actuators B: Chemical, 171172: $907-915$.

22. Guaratini, C. C. I., Fogg, A. G. and Zanoni, M. V. B. (2001). Assesment of the application of cathodic stripping voltammetry to the analysis of diazo reactive dyes and their hydrolysis products. Dyes and Pigment, 50: $211-$ 221.

23. Menek, N. and Karaman, Y. (2006). Polarographic and voltammetric investigation of 6'-butoxy-2,6-diamino3,3'-azodipyridine. Dyes and Pigments, 68: $101-108$.

24. Mo, Z., Zhang, Y. M., Zhao, F., Xiao, F., Guo, G. and Zeng, B. (2010). Sensitive voltammetric determination of Sudan I in food samples by using Gemini surfactant-ionic liquid-multiwalled carbon nanotube composite film modified glassy carbon electrodes. Food Chemistry, 121: $233-237$.

25. Ucar, M., Polat, K., Solak, A.O., Toy, M. and Aksu, M. L. (2010). The electrochemical behavior of 2halogenated derivatives of 4-methoxyazobenzene at a mercury electrode. Dyes and Pigments, 87: 55 -61.

26. Wu, Y. (2010). Electrocatalysis and sensitive determination of Sudan I at the single-walled carbon nanotubes and iron (III)-porphyrin modified glassy carbon electrodes. Food Chemistry, 121: $580-584$.

27. Vilaseca, C., Quintana, M.C., Vicente, J., Hernández, P. and Hernández, L. (2008). Electrochemical analysis of the alanine phenylthiohydantoin derivative by cathodic stripping voltammetry. Analytical Biochemistry, 379: 91 -95 .

28. Bagheri, A. and Hosseini, H. (2012). Electrochemistry of raloxifane on glassy carbon electrode and its determination in pharmaceutical formulations and human plasma. Bioelectrochemistry, 88: $164-170$.

29. Aşangil, D., Taşdemir, İ. H. and Kılıc, E. (2012). Adsorptive stripping voltammetric methods for determination of aripiprazole. Journal of Pharmaceutical Analysis, 2(3): 193 - 199. 
30. Ardila, J. A., Sartori, E. R., Rocha-Filho, R. and Fatibello-Filho, O. (2013). Square-wave voltammetric determination of bezafibrate in pharmaceutical formulations using a cathodically pretreated boron-doped diamond electrode. Talanta, 103: $201-206$.

31. Jain, R. and Vikas. (2011). Voltammetric behavior of antimalarial drug artesunate in solubilized systems. Colloids and Surfaces B: Biointerfaces, 88: 729 - 733.

32. Malode, S. J., Shetti, N. P. and Nandibewoor, S. T. (2012). Voltammetric behavior of theophylline and its determination at multi-wall carbon nanotube paste electrode. Colloids and Surface B: Biointerfaces, 97: 1 - 6.

33. Hadzri, M.Y. (2006). Stripping voltammetric methods for the determination of aflatoxin compounds. $\mathrm{PhD}$ thesis, Universiti Teknologi Malaysia.

34. Guo, Y. J., Pan, J. H. and Jing, W. J. (2004). Determination of Orange II and the supramolecular system of Orange II with cyclodextrins by polarography. Dyes and Pigments, 63: 65 - 70.

35. Brahman, P. K., Dar, R. A. and Pitre, K. S. (2013). Adsorptive stripping voltammetric study of Vitamin B1 at multi-walled carbon nanotube paste electrode. Arabian Journal of Chemistry, Article in Press.

36. Gupta, V. K., Jain, R., Agarwal, S., Mishra, R. and Dwivedi, A. (2011). Electrochemical determination of antihypertensive drug irbesartan in pharmaceuticals. Analytical Biochemistry, 410: $266-271$.

37. Rievaj, M., Švorc, L. and Bustin, D. (2013). Green electrochemical sensor for environmental monitoring of pesticides: Determination of atrazine in river waters using a boron-doped diamond electrode. Sensors and Actuators B: Chemical, 181: $294-300$.

38. Jain, R. and Sharma, R. (2012). Cathodic adsorptive stripping voltammetry of an anti-emetic agent Granisetron in pharmaceutical formulation and biological matrix. Journal of Pharmaceutical Analysis, 2(6): $443-449$.

39. Tavares., E. M., Carvalho, A. M., Gonçalves, L. M., Valente, I. M., Moreira, M. M., Guido, L. F., Rodrigues, J. A., Doneux, T. and Barros, A. A. (2013). Chemical sensing of chalcones by voltammetry: trans-Chalcone, cardamonin and xanthohumol. Electrochimica Acta, 90: 440 - 444.

40. Chaiyo, S., Chailapakul, O., Sakai, T., Teshima, N. and Siangproh, W. (2013). Highly sensitive determination of trace copper in food by adsorptive stripping voltammetry in the presence of 1,10-phenanthroline. Talanta, 108: $1-6$.

41. De Lima, F., Gozzi, F., Fiorucci, A. R., Cardoso, C. A. L., Arruda, G. J. and Ferreira, V. S. (2011). Determination of linuron in water and vegetable samples using stripping voltammetry with carbon paste electrode. Talanta, 83: $1763-1768$.

42. Geremedhin, W., Amare, M. and Admassie, S. (2013). Electrochemically pretreated glassy carbon electrode for electrochemical detection of fenitrothion in tap water and human urine. Electrochimica Acta, 87: 749 - 755.

43. Radi, A. E., Khafagy, A., El-Shobaky, A. and El-Mezayen, H. (2013). Anodic voltammetric determination of gemifloxacin using screen printed carbon nanotube. Journal of Pharmaceutical Analysis, 3(2): 132 - 136.

44. Sadeghi, S., Motaharian, A. and Moghaddam, A. Z. (2012). Electroanalytical determination of sulfasalazine in pharmaceutical and biological samples using molecularly imprinted polymer modified carbon paste electrode. Sensors and Actuators B: Chemical, 168: 336 - 344.

45. Yang, G., Chen, Y., Li, L. and Yang, Y. (2011). Direct electrochemical determination of morphine on a novel gold nanotube arrays electrode. Clinica Chimica Acta, 412: 1544 - 1549.

46. Salles, M. O., Naozuka, J. and Bertotti, M. (2012). A forensic study: Lead determination in gunshot residues. Microchemical Journal, 101: $49-53$.

47. Skrzypek, S., Mirčeski, V., Ciesielski, W., Sokolowski, A. and Zakrzewski, R. (2007). Direct determination of metformin in urine by adsorptive catalytic square-wave voltammetry. Journal of Pharmaceutical and Biomedical Analysis, 45: 275 - 278.

48. Elqudaby, H. M., Mohamed, G. G., Ali, F. A. and Eid, S. M. (2011). Validated voltammetric method for the determination of some antiprotozoa drugs based on the reduction at an activated glassy carbon electrode. Arabian Journal of Chemistry, 6: 327 - 333.

49. Mohamed, D. and Tawakkol, S. N. (2013). Fluorimetric determination of diosmin and hesperidine in combined dosage forms and in plasma through complex formation with terbium. Bulletin of Faculty of Pharmacy Cairo University, 51: $81-88$.

50. Baig, J. A., Kazi, T.G., Shah, A. Q., Kandhro, G. A., Afridi, H. I., Arain, M. B., Jamali, M. K. and Jalbani, N. (2010). Speciation and evaluation of Arsenic in surface water and groundwater samples: A multivariate case study. Ecotoxicology and Environmental Safety, 73: 914 - 923. 
51. Bergamini, M. F., Santos, D. P. and Zanoni, M. V. B. (2010). Determination of isoniazid in human urine using screen printed carbon electrode modified with poly-_-histidine. Bioelectrochemistry, 77: 133 - 138.

52. Radi, A. E., Mostafa, M. R., Hegazy, T. A. and Elshafey, R. M. (2012). Electrochemical study of vinylsulphone azo dye Reactive Black 5 and its determination at a glassy carbon electrode. Journal of Analytical Chemistry, 67: 890 - 894 .

53. Rivera, M., Pazos, M. and Sanromán, M. Á. (2011). Development of an electrochemical cell for the removal of Reactive Black 5. Desalination, 274: 39 - 43. 